\title{
Application of a conceptual precipitation-runoff model (HYGYMODEL) in a debris-covered glacierized basin in the Langtang Valley, Nepal Himalaya
}

\author{
Birbal Rana, Masayoshi Nakawo, Yoshiniro Fukushima, Yutaka Ageta \\ Institute for Hydrospheric-Atmospheric Sciences, Nagoya University, Nagoya 464-01, Japan
}

\begin{abstract}
A conceptual precipitation-runoff model (HYCYMODEL) is used to simulate the daily runoff from the $67 \%$ glacierized Lirung basin $16 \%$ of which is covered by debris). The average thermal resistance of the debris cover of the Lirung Glacier has been estimated from the surface temperature of the debris, which was obtained from Landsat 5 (TM Band 6) images. This enabled calculation of the melt rate of the debriscovered area of the glacier using meteorological data collected at a nearby weather station. The calculated discharge results are roughly compatible with the observed daily discharges.
\end{abstract}

\section{INTRODUCTION}

It is of fundamental importance in Nepal to be able to estimate glacier ablation under the debris layer, since the meltwater from glaciers is one of the major water sources for the country. In Nepal, most of the ablation areas of glaciers are covered with debris (Fujii and Higuchi, 1977). However, no reliable estimates have been made as yet regarding the precise amount of ablation under the debris layer.

The relation between the rate of ablation and debris thickness has been studied by many workers (e.g. Ostrem, 1959; Loomis, 1970; Fujii, 1977; Mattson and others, 1993) The presence of a debris layer at the ice surface means that the ablation rate underneath it is accelerated when the debris layer is thin, while the ablation rate is retarded when debris is thick. This general finding is reported in the results of many researchers, but results vary as to the thickness required before ablation is accelerated or suppressed. In addition, the debris thickness at which maximum ablation takes place varies between studies, along with, the maximum rate of ablation. These discrepancies can be explained in terms of the different thermal properties of debris and/or the different meteorological conditions when experiments or observations were carried out (Nakawo and Young, 1981). It is important, therefore, to take into account not only debris thickness, but both the thermal properties of the debris and the meteorological conditions for examining ablation under a debris layer (Nakawo and Takahashi, 1982).

In order to estimate glacier melt from the whole ablation area of debris-covered glaciers, it is necessary to know, in addition to meteorological conditions, the distribution of debris thickness and its thermal properties. It is very difficult, however, to measure debris distribution in the field, partly because it varies between geographical areas, and partly because collecting such data is dangerous and it is sometimes impossible to assess the entire surface of debriscovered glaciers. In the past, therefore, runoff models have been based on a variety of assumptions regarding debris characteristics for debris-covered glaciers.

The present study was conducted in the Lirung basin, located in the Langtang Valley, approximately $60 \mathrm{~km}$ north of Kathmandu, Nepal. Glacial discharge modeling in this area has been attempted by Braun and others (1993), who mentioned that the predictions of a conceptual runoff model agree roughly with field data if the ablation under the debris is regarded to be half the ablation of debris-free glacier ice. Rana and others (1996) suggested assuming an average debris thickness of $0.5-1 \mathrm{~m}$, with a thermal conductivity of 1.4-2.6 $\mathrm{Wm}^{-1} \mathrm{deg}^{-1}$.

Nakawo and Young (1982) showed that the ablation rate under a debris layer can be estimated only by meteorological variables if the surface temperature of the debris is given. Nakawo and others (1993) proposed that the distribution of surface temperature could be estimated by using satellite data: therefore it is possible to estimate ablation from large debris-covered areas. The present paper uses this methodology to estimate the ablation rate of a debris-covered glacier and then compares the results with field discharge data.

\section{BASIN DESCRIPTION}

Figure 1 is a topographical map of the Lirung basin with the hydrological site $(\mathrm{Sl})$, and the meteorological observation site $(\mathrm{BH})$ at an altitude of $3920 \mathrm{~m}$ a.s.l. Hydrometeorological observations have been taken regularly at $\mathrm{BH}$ since 1987 by the Department of Hydrology and Meteorology, Nepal. The total basin area is $13.8 \mathrm{~km}^{2}$, of which $51 \%$ is debris-free ice, $16 \%$ debris-covered glacier, and the remaining $33 \%$ comprises steep, rocky walls.

From the 1:50000 map published by the Austrian Alpine Club (1990) areal distribution of debris-free and debris-covered ice were derived at $200 \mathrm{~m}$ altitudinal spans for the present model calculation as shown in Figure 2. Lirung Glacier is heavily debris-covered at its lower elevations. The average debris thickness around $4400 \mathrm{~m}$ a.s.l. was approximately $0.5 \mathrm{~m}$ (K. Fujita, personal communication, 1996). The 


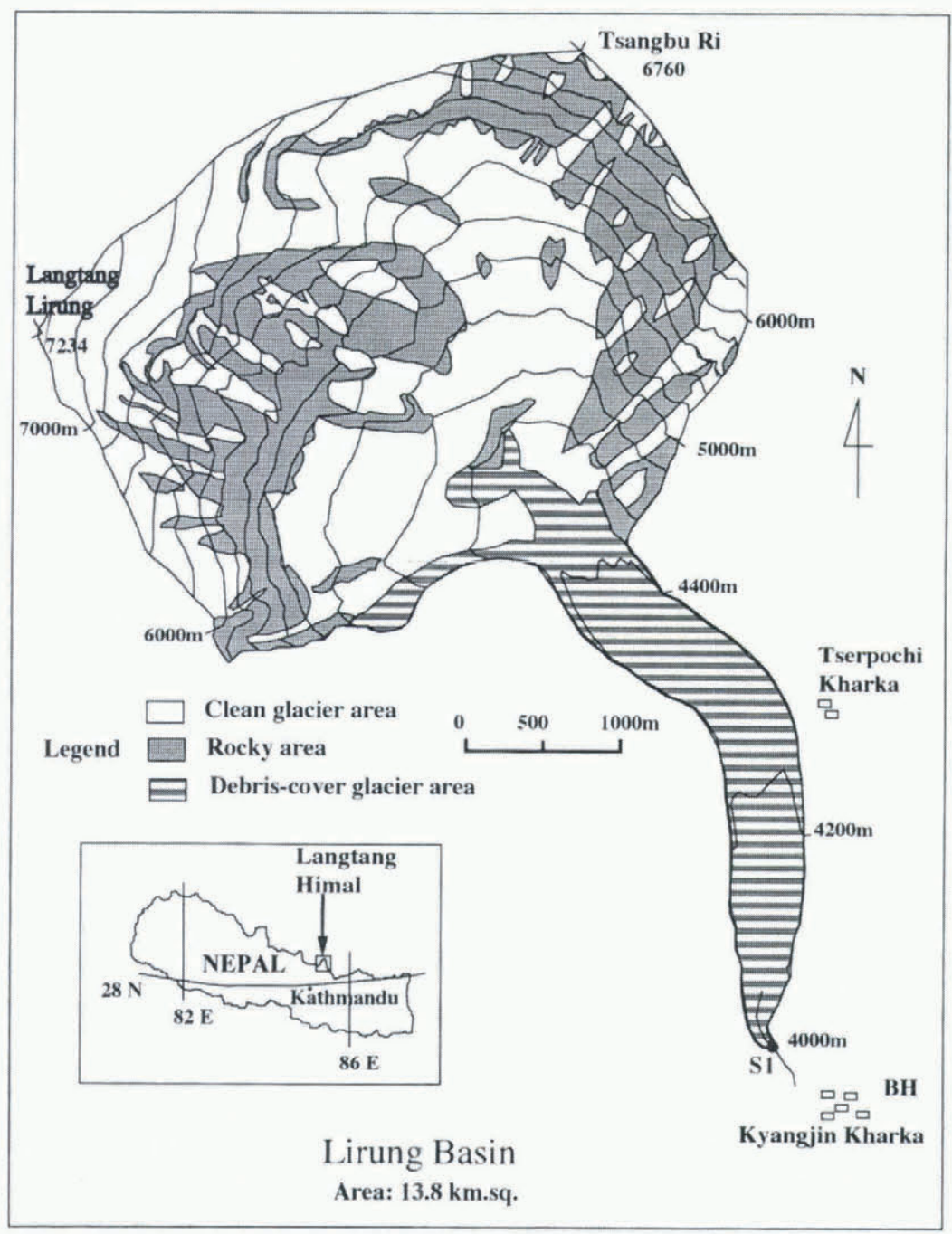

Fig. 1. Topographical map of the Lirung basin in Nepal. S1 shows the location of the hydrological station and BH represents the

"Base House" where the meteorological observations were made.

albedo of the debris surface varied with a mean value of about 0.1 .

\section{THE MODEL AND DATA}

\section{Runoff Model}

The HYCYMODEL treats snow and ice meltwater the

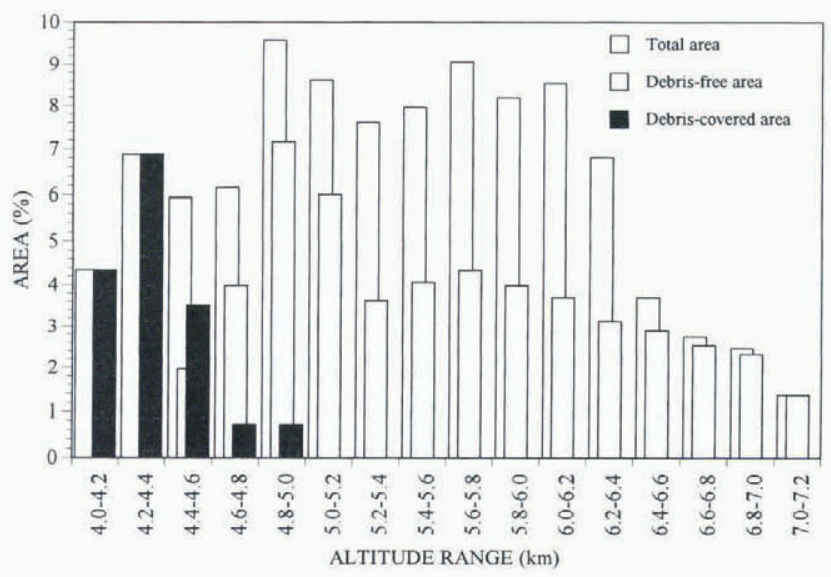

Fig. 2. Altitudinal distribution of the Lirung drainage basin and the glacier areas included at $200 \mathrm{~m}$ intervals (the area of debris-free glacier is $51 \%$, debris-covered glacier is $16 \%$, and the rocky wall is $33 \%$ of the total basin). same as rainfall. This model is the same kind of conceptual runoff model that was developed for a small forested mountain catchment by Fukushima (1988). The schematic representation of the model is shown in Figure 3. Effective rainfall, $R e(t)$, is determined by the mean effective soildepth parameter and its deviation (in the present case, evaporation is neglected), $S u$ is a linear upper-storage tank, $S b$

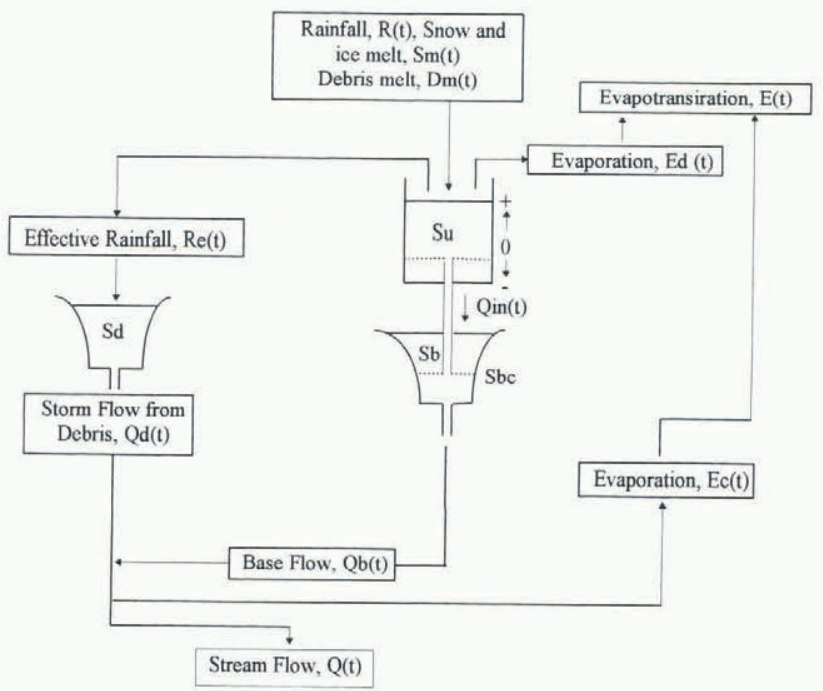

Fig. 3. Schematic representation of the modified HYCYMODEL. 
a non-linear lower-storage tank, and $S d$ is a non-linear tank for storm flow.

This model was used to simulate the stream flow with daily precipitation and daily mean air-temperature data for the $45 \%$ glacierized Langtang basin in the Nepal Himalaya (Fukushima and others, 1991). The observed streamflow was simulated well in the period between July 1985 and April 1986.

\section{Precipitation and melt for debris-free glacier surfaces}

That precipitation increases with altitude is usually true in the glacier areas in the Nepal Himalaya (Higuchi and others, 1982). In the Langtang Valley, the precipitation at $5000 \mathrm{~m}$ was 1.3 times greater than at $4000 \mathrm{~m}$ (Seko, 1987). Since precipitation data were available from $\mathrm{BH}$ only, the current study made the assumption that precipitation is a function of altitude as follows:

$$
\begin{aligned}
& P_{\mathrm{z}}=P_{\mathrm{BH}} \quad \text { when } \quad z<4000 \mathrm{~m} \\
& P_{\mathrm{z}}=P_{\mathrm{BH}}(1+0.0003(z-4000)) \\
& \text { when } 4000 \mathrm{~m} \leq z \leq 5000 \mathrm{~m} \\
& P_{\mathrm{z}}=1.3 P_{\mathrm{BH}} \quad \text { when } \quad z>5000 \mathrm{~m}
\end{aligned}
$$

where, $P_{\mathrm{z}}$ is precipitation at altitude $z$ meters (in $\mathrm{mm}$ ), $P_{\mathrm{BH}}$ is precipitation observed at $\mathrm{BH}$, located at $3920 \mathrm{~m}$ a.s.l. (in $\mathrm{mm}$ ).

The Lirung basin was divided into 16 altitude zones of $200 \mathrm{~m}$ intervals. Rainfall, snow melt and ice melt were calculated at each zone. The critical air temperature between snowfall and rainfall was estimated as $2.0^{\circ} \mathrm{C}$ (Ageta and others, 1980). The lapse rate was taken to be $-0.6^{\circ} \mathrm{C} / 100 \mathrm{~m}$.

For calculating snow melt and ice melt from debris-free areas, the empirically derived relation for Glacier AX 010 in eastern Nepal (Ageta and others, 1980), was used:

$$
\begin{array}{ll}
S M_{\mathrm{O}}=0 & \text { when } \quad T<-3.0 \\
S M_{\mathrm{O}}=0.1(3.0+T)^{3.2} & \text { when } \quad T \geq-3.0
\end{array}
$$

where, $S M_{\mathrm{O}}$ is the daily snow melt and ice melt from debrisfree areas (in $\mathrm{mm}$ ) and $T$ is the daily mean air temperature (in $\mathrm{C}$ ).

\section{Ablation under a debris layer}

To evaluate glacier ablation under a debris layer, Nakawo and Young (1982) successfully proved that the surface temperature of the debris layer can be used for estimating the thermal properties of unknown material, assuming a linear temperature profile in the debris layer. Figure $4 \mathrm{a}$ shows an image from Landsat 5 TM Band 2 depicting areas of relatively high intensity reflected radiation with bright color. Scattered dark spots can be seen over the glacier, indicating schistose-type dark-colored debris material (Inoue and Yoshida, 1980).

A Landsat 5 TM Band 6 image from 8 May 1989 was used to derive the distribution of the surface temperature of the debris layer (Fig. 4b) since no images for 1985-86 were available. With the surface temperature, the thermal resistance $(R)$ of the surface debris was also calculated using meteorological data taken at the same time as the satellite image, following the model of Nakawo and Young, (1982).

The general energy-balance equation at the surface layer of a glacier is:

$$
F_{\mathrm{r}}+F_{\mathrm{h}}+F_{\mathrm{l}}=F_{\mathrm{m}}
$$

where $F_{\mathrm{r}}$ is radiation heat flux $\left(\mathrm{W} \mathrm{m}^{-2}\right), F_{\mathrm{h}}$ is sensible heat flux $\left(\mathrm{W} \mathrm{m}^{-2}\right), F_{1}$ is latent heat flux $\left(\mathrm{W} \mathrm{m}^{-2}\right)$ and $F_{\mathrm{m}}$ is the heat available to melt ice $\left(\mathrm{W} \mathrm{m}^{-2}\right)$. All the flux terms are taken to be positive downward.

Radiation heat flux is calculated from the equation:

$$
F_{\mathrm{r}}=Q(1-\alpha)+I_{\mathrm{i}}-I_{\mathrm{o}}
$$

where $Q$ is incoming solar radiation $\left(\mathrm{W} \mathrm{m}^{-2}\right), \alpha$ is surface albedo, $I_{1}$ is incoming longwave radiation $\left(\mathrm{W} \mathrm{m}^{-2}\right)$ and $I_{\mathrm{o}}$ is outgoing longwave radiation $\left(\mathrm{W} \mathrm{m}^{-2}\right)$.

The incoming longwave radiation can be calculated (Kondo, 1967) by:

$$
I_{\mathrm{i}}=\sigma\left(T_{\mathrm{a}}+273\right)^{4}\left\{1-\left(0.49-0.066 \sqrt{e_{\mathrm{a}}}\right) C_{\mathrm{c}}\right\}
$$

and the outgoing longwave radiation by:

$$
I_{\mathrm{o}}=\sigma\left(T_{\mathrm{s}}+273\right)^{4}
$$

where $\sigma$ is the Stefan-Boltzmann constant $5.67 \times 10^{-8} \mathrm{~W} \mathrm{~m}^{-2}$ $\left.\mathrm{K}^{4}\right), R_{\mathrm{a}}$ is air temperature $\left({ }^{\circ} \mathrm{C}\right), T_{\mathrm{s}}$ is surface temperature $\left({ }^{\circ} \mathrm{C}\right), e_{\mathrm{a}}$ is the vapor pressure of air $(\mathrm{mb})$ and $C_{\mathrm{c}}$ depends on vapor pressure, cloud type and cloud thickness.

The sensible and latent heat flux is calculated by the bulk aerodynamic method:

$$
\begin{aligned}
F_{\mathrm{h}} & =\beta U_{\mathrm{a}}\left(T_{\mathrm{a}}-T_{\mathrm{s}}\right) \\
F_{\mathrm{l}} & =\beta U_{\mathrm{a}} L_{\mathrm{e}} \frac{0.622}{p c_{\mathrm{p}}}\left(e_{\mathrm{a}}-e_{\mathrm{s}}\right)
\end{aligned}
$$

where $\beta$ is the heat transfer coefficient $\left(4.89 \mathrm{~J} \mathrm{~m}^{-3} \mathrm{deg}^{-1}\right), U_{\mathrm{a}}$ is wind speed $\left(\mathrm{m} \mathrm{s}^{-1}\right), L_{\mathrm{e}}$ is the latent heat of evaporation $\left(2494 \mathrm{~J} \mathrm{~g}^{-1}\right) p$ is pressure $(\mathrm{mb}), c_{\mathrm{p}}$ is the specific heat capacity of air at constant pressure $\left(1.0 \mathrm{Jg}^{1} \mathrm{deg}^{-1}\right)$ and $e_{\mathrm{s}}$ is vapor pressure at the glacier surface $(\mathrm{mb})$.

The assumptions made in the model are that the stored heat in the debris layer is constant as the time-step is one day, and the temperature in the debris layer is in a stationary state, i.e.:

$$
F_{\mathrm{m}}=\frac{T s}{R}
$$

where $R$ is the thermal resistance of the debris layer $\left(\mathrm{m}^{2} \operatorname{deg} \mathrm{W}^{-1}\right.$ ).

With the value for $R$ thus estimated, glacier ablation under the debris layer was calculated again utilizing the Nakawo and Young (1982) model for meteorological conditions during the period in question.

\section{RESULTS AND DISCUSSION}

The temperature along a transverse line in different parts of the Lirung Glacier is shown in Figure 5. Figure $4 \mathrm{~b}$ and Figure 5 show that debris-surface temperature is lower on the glacier surface than on the lateral moraines, which indicates that the debris-surface temperature is lowered by the presence of the ice body underneath. Ground observations revealed that ice cliffs and ponds are predominant on the left side of the glacier, where temperature is comparatively low. It can be seen that the maximum and minimum temperatures on all transverse lines are similar (i.e. the range is small), indicating a generally uniform distribution of debris material over the length of the glacier. This is in contrast to data from Khumbu Glacier (Nakawo and others, 1986) where temperature distribution was not uniform.

The maximum temperature of lateral moraines range on the glacier are in the $25-35^{\circ} \mathrm{C}$, and the minimum temperature range is $4-6^{\circ} \mathrm{C}$. Similar results were obtained when airborne measurements of surface temperatures were made 

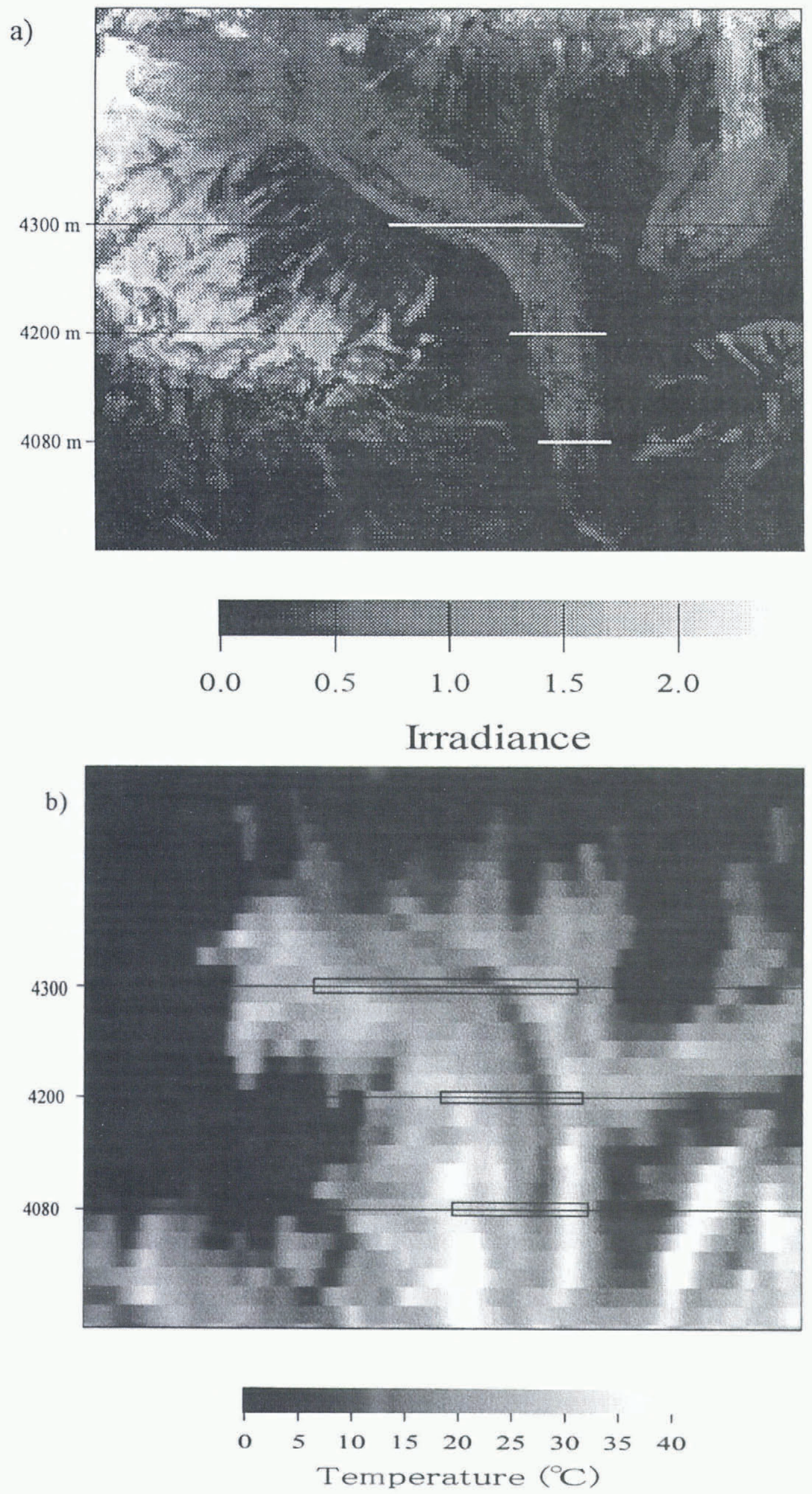

Fig. 4. Distribution of a) high radiation intensity in TM 2 and b) surface temperature from TM Band 6 of LA.NDSAT 5 on 8 May 1989 in the debris-covered area of the Lirung Glacier. 

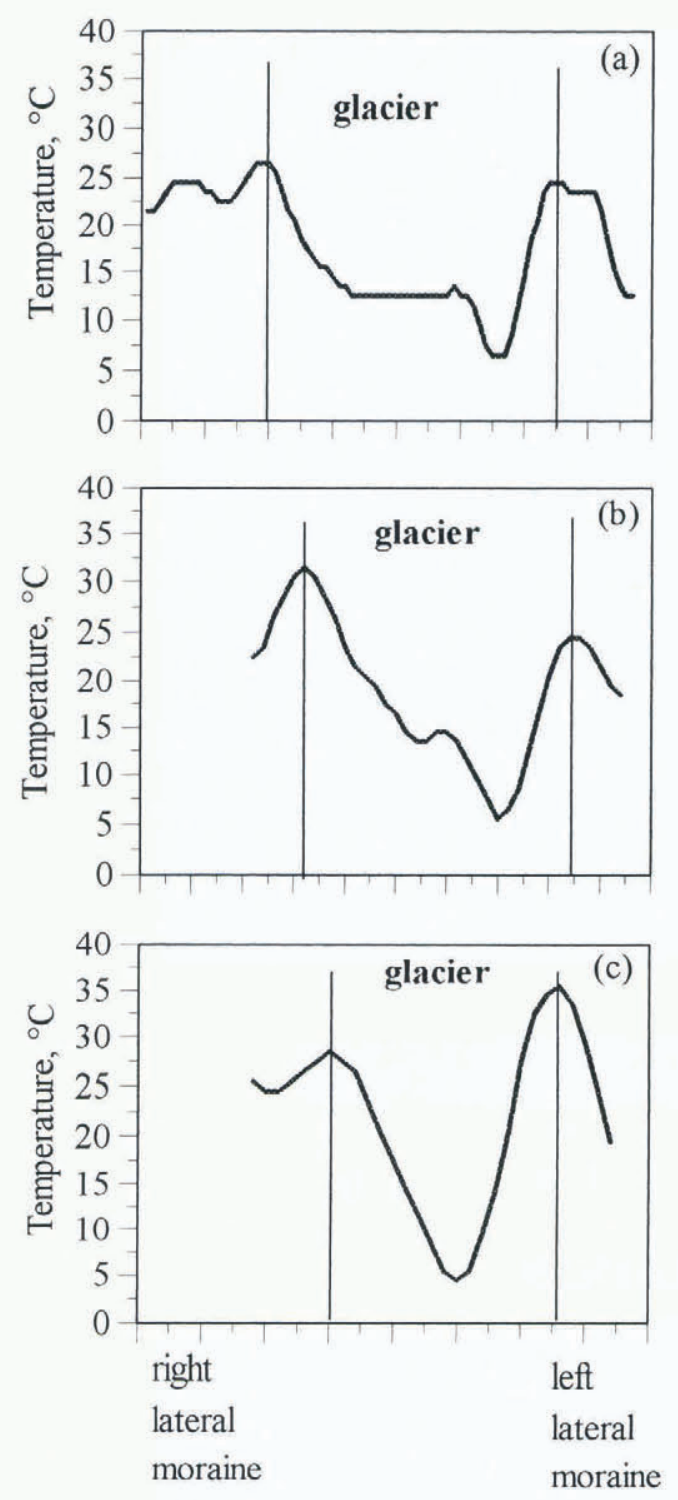

Fig. 5. Transversal temperature profile along the white lines indicated on Fig. $4 a$ of the Lirung Glacier derived from LANDSAT 5 TM Band 6 on 8 May 1989 at a) $4300 \mathrm{~m}$, b) $4200 \mathrm{~m}$ and c) $4080 \mathrm{~m}$ a.s.l. by IR radiometer at another debris-covered glacier in eastern Nepal (Yasunari, 1980). The resolution of a unit pixel in TM Band 6 is $120 \mathrm{~m}$, which is rather large for the Lirung basin, the approximate width of which is only $500 \mathrm{~m}$.

The average surface temperature was calculated, for the whole debris-covered area, as $12^{\circ} \mathrm{C}$. This value gave a thermal resistance of about $0.14 \mathrm{~m}^{2} \operatorname{deg} \mathrm{W}^{-1}$ as a mean value for the whole debris cover. Using this thermal resistance, the daily ablation from the debris-covered area was calculated with the meteorological parameters observed at $\mathrm{BH}$ from July 1985 to June 1986, making the assumption that the debris condition had not changed between 1985 and 1989.

Figure 6 shows a comparison of the daily discharges from July to September 1985, calculated for different basin conditions as follows (a) assuming the whole drainage basin is debris-free, (b) assuming no melt from the debris-covered areas, and (c) with melt under the debris layer calculated with the constant thermal resistance derived from the satellite data. When the basin is assumed to be debris-free, (a) the simulated discharge is higher than the observed discharge. In the case of no melt from the debris-covered area (b), the simulated discharge is much smaller than the observed value. The ablation under the debris layer (c) has results most compatible with the field data. This indicates that the estimation of glacier ablation under the debris layer is necessary for runoff modeling. It can be seen that the case that included the melt from the debris area improved the result by $20 \%$ more than the case of no melt from the debris-covered area.

Although the total discharge for 30 July-13 August agrees fairly well with the field data, the mean discharge for the beginning and the end of the observation period is underestimated by $30 \%$. This discrepancy might be attributed to the averaged surface temperature used in the calculation. Since the relationship between the rate of ablation and the surface temperature is non-linear, the areas with the lowest surface temperatures would produce more meltwater than that estimated. It is necessary, therefore, to obtain a map of surface-temperature variability using higher resolution techniques, and to assess the contribution of individual sites in more detail.

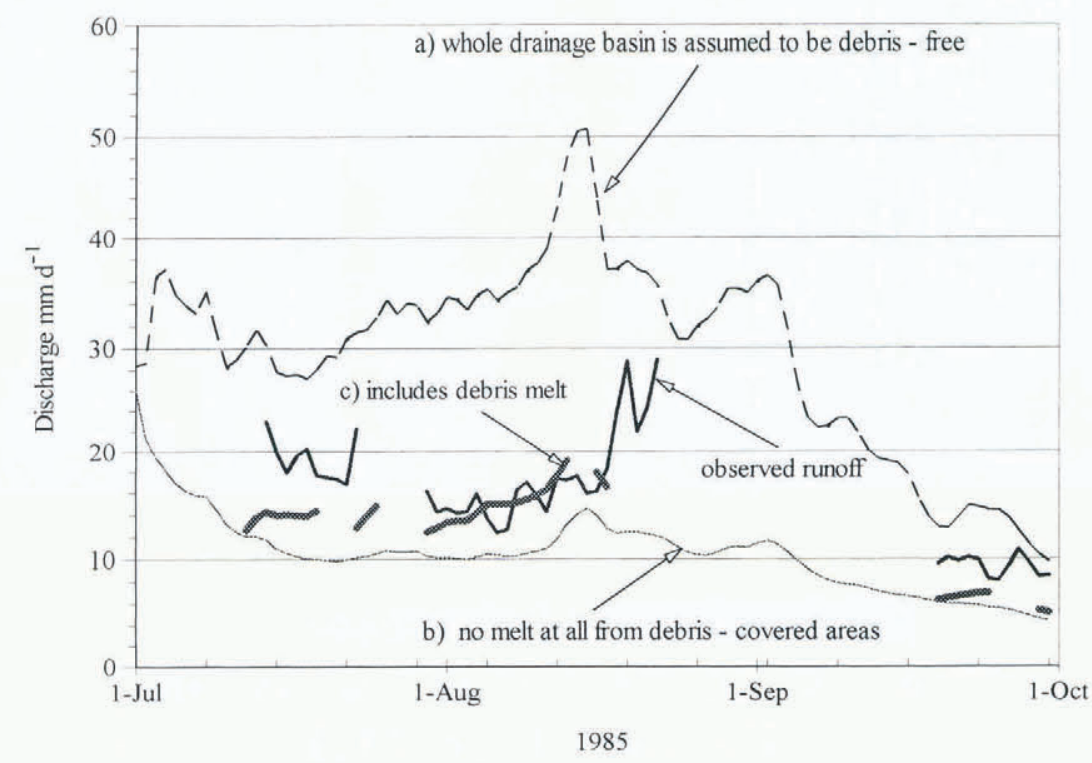

Fig. 6. Comparison of daily observed discharge to simulated runoff in the Lirung drainage basin using the HXCYMODEL, including the melt from the debris zones. 


\section{CONCLUDING REMARKS}

Satellite data can be used to derive surface-temperature data from Landsat 5 TM Band 6 images. The glacier-ablation rate calculated on the basis of average thermal properties of unknown debris material derived from satellite data improved the modeled results. However, a further study of ground and airborne observations is required to obtain a better understanding of the distribution of surface temperatures. Detailed study of debris distribution, with higher resolution of surface temperature, would greatly improve the estimates of glacier ablation under debris layers, and, accordingly, the estimate of discharge from debris-covered glacier basins.

\section{ACKNOWLEDGEMENTS}

The authors are grateful to K. Seko and H. Yabuki of the Laboratory of Cryosphere Variation, Institute for Hydrospheric-Atmospheric Sciences, for helping to acquire and process the satellite data.

\section{REFERENCES}

Ageta, Y., T. Ohata, Y. Tanaka, K. Ikegami and K. Higuchi. 1980. Mass balance of glacier AX010 in Shirong Himal, east Nepal during the summer monsoon season. Seppyo, J. Jpn. Soc. Snow Ice, 41, Special Issue, $34-41$.

Austrian Alpine Club. 1990. Alpenvereinskarte Langthang Himal. Vienna Freytag-Berndt and Artaria. (Expedition maps $0 / 10$ (West) and $0 / 11$ (Ost . Scale 1:50,000

Braun, L.N., W. Grabs and B. Rana. 1993. Application of a conceptual precipitation-runoff model in the Langtang Khola basin, Nepal Himalaya. International Association of Hydrological Sciences Publication 218 (Symposium at Kathmandu 1992 - Snow and Glacier Hydrology , 221-237.

Fujii, Y. 1977. Field experiment on glacier ablation under a layer of debris cover. Seppyo, J. Jpm. Soc. Snow Ice, 39, Special Issue, 20-21.

Fujii, Y. and K. Higuchi. 1977. Statistical analyses of the forms of the glaciers in Khumbu region. Seppyo, J. Jpn. Soc. Snow Ice, 39, Special Issue, 7-14.

Fukushima, Y. 1988. A model of river flow forecasting for a small mountain catchment. Hydrol. Processes, 2, 167-185.
Fukushima, Y., O. Watanabe and K. Higuchi. 1991. Estimation of streamflow change by global warming in a glacier-covered high mountain area of the Nepal Himalaya. International Association of Hydrological Sciences Publication 205 (Symposium at Vienna 1991 - Snow, Hydrology and Forests in High Alpine Areas), $181-188$.

Higuchi, K., Y. Ageta, T. Yasunari and J. Inoue. 1982. Characteristics of precipitation during the monsoon season in high-mountain areas of the $\mathrm{Ne}$ pal Himalaya. International Association of Hydrological Sciences Publication 138 Symposium at Exeter 1982 Hydrological Aspects of Alpine and High Mountain Areas), $21-30$.

Inoue, J. and M. Yoshida. 1980. Ablation and heat exchange over the Khumbu glacier. Seppyo, J. Jpn. Soc. Snow Ice, 41, Special Issue, 26-33.

Kondo, J. 1967. Analysis of solar radiation and downward long-wave radiation data in Japan. Sci. Rep. Tohoku Uniz., Ser. 5, 18 (3), 91-124.

Loomis, S. R. 1970. Morphology and ablation processes on glacier ice. Proc. Assoc. Am. Geogr. Proc., 2, 88-92.

Mattson, L. E., J. S. Gardner and G. J. Young. 1993. Ablation on debris covered glaciers: an example from the Rakhiot Glacier, Punjab, Himalaya. International Association of Hydrological Sciences Publication 218 Symposium at Kathmandu 1992 - Snow and Glacier Hydrology), $289-296$.

Nakawo, M. and S. Takahashi. 1982. A simplified model for estimating glacier ablation under a debris layer. International Association of Hydrological Sciences Publication 138 (Symposium at Exeter 1982 - Hydrological Aspects of Alpine and High Mountain Areas), 137-145.

Nakawo, M. and G.J. Young. 1981. Field experiments to determine the effect of a debris layer on ablation of glacier ice. Ann. Glaciol., 2, 85-91.

Nakawo, M. and G. J. Young. 1982. Estimate of glacier ablation under a debris layer from surface temperature and meteorological variables. 7. Glaciol., 28 (98), $29-34$.

Nakawo, M., S. Iwata, O. Watanabe and M. Yoshida. 1986. Processes which distribute supraglacial debris on the Khumbu Glacier, Nepal Himlaya. Ann. Glaciol., 8, 129-131.

Nakawo, M., T. Morohoshi and S. Uehara. 1993. Satellite data utilization for estimating ablation of debris covered glaciers. International Association of Hydrological Sciences Publication, 218, Symposium at Kathmandu 1992 - Snow and Glacier Hydrology, , 75-83.

Ostrem, G. 1959. Ice melting under a thin layer of moraine, and the existence of ice cores in moraine ridges. Geogr. Ann., 41 (4), 228-230.

Rana, B., Y. Fukushima, Y. Ageta and M. Nakawo. 1996. Runoff modeling of a river basin with a debris-covered glacier in Langtang Valley, Nepal Himalaya. Bull. Glacier Res. 14, 1-6.

Seko, K. 1987. Seasonal variation of altitudinal dependence of precipitation in Langtang valley, Nepal Himalayas. Bull. Glacier Res. 5, 41-47.

Yasunari, T. 1980. Air-borne measurements of the surface temperature over Nepal Himalayas. Seppyo, 7. Jpn. Soc. Snow Ice, 41, Special Issue, $82-85$. 